\title{
Bacteriophage M: an Incompatibility Group M Plasmid-specific Phage
}

\author{
By J. N. COETZEE, ${ }^{1 *}$ D. E. BRADLEY,${ }^{2}$ R. W. HEDGES,$^{3}$ JEANETTE \\ FLEMING ${ }^{2}$ AND G. LECATSAS ${ }^{1}$ \\ ${ }^{1}$ Department of Microbiology, University of Pretoria and Bacterial Genetics Research Unit of the \\ South African Medical Research Council, P.O. Box 2034, Pretoria 0001, South Africa \\ ${ }^{2}$ Faculty of Medicine, Memorial University of Newfoundland, St. John's, Newfoundland \\ AlB 3V6, Canada \\ ${ }^{3}$ Plant Genetic Systems, Rijksuniversiteit Gent, Jozef Plateau Straat 22, B9000 Gent, Belgium
}

(Received 1 February 1983; revised 14 March 1983)

\begin{abstract}
Phage $\mathbf{M}$ was specific for bacterial strains, of various genera, harbouring plasmids of the $\mathbf{M}$ incompatibility group. It formed turbid plaques which varied from pin point to more than $2 \mathrm{~mm}$ in diameter on all hosts where plaques were detected. The phage had an hexagonal outline with a diameter of $27 \mathrm{~nm}$. It contained RNA but differed from other plasmid-dependent RNA phages in being sensitive to chloroform. It adsorbed along the length of shafts of $M$ pili.
\end{abstract}

\section{INTRODUCTION}

The IncM plasmid incompatibility group (for Morgan, 1906) was established to accommodate plasmid R446b present in a strain of Proteus morganii, which was compatible with representative plasmids of all incompatibility groups tested (Hedges et al., 1973). Datta (1975) and Novick et al. (1976) listed IncM and Com7, an incompatibility group named by Chabbert $e t$ al. (1972), as synonymous, but the tendency is to abandon the latter designation in favour of the former (Datta, 1979; Richards \& Datta, 1979). Some plasmids from Serratia marcescens were described as being members of incompatibility group L (Hedges et al., 1975), but these were shown to be typical members of group M with molecular masses of 40-65 MDal (Richards \& Datta, 1979) and plasmids ascribed to the former group are now included in the latter.

IncM plasmids code for pili which are rigid and belong to morphological group 3 (Bradley, $1980 \mathrm{~b}$ ). These plasmids render bacterial hosts sensitive to the wide host-range filamentous phage X (Bradley et al., 1981a). Here is reported the isolation and some properties of a new phage specific for bacteria carrying these plasmids.

\section{METHODS}

Bacteria and plasmids. Escherichia coli strains were J53, J53-2, J62-1 (Datta et al., 1980) and JE2571 (Bradley, $1980 a$ ). Klebsiella pneumoniae strain G162 and $K$. oxytoca strain G147 were provided by Dr I. Simpson, Glaxo Research, Greenford, Middlesex, U.K. The Salmonella typhimurium strain was M827-2, a spontaneous rif mutant of LT2 strain M827 (Spratt et al., 1973); Serratia marcescens Sr41 (Matsumoto et al., 1973) was provided by Dr H. Matsumoto. Proteus mirabilis strain PM5006 (Coetzee \& Smit, 1970) and P. morganii 2815 (Coetzee, 1972) were also used. Plasmids originated from the collection of Naomi Datta (Datta, 1977, 1979). Apart from plasmids belonging to the IncM incompatibility group (see Table 1), only those which encoded constitutive pilus synthesis (as judged by a transfer frequency of greater than $10^{-3}$ per bacterium $\mathrm{h}^{-1}$ or by plaque formation by appropriate plasmid-specific phages) were used. Thus one or more plasmids belonging to Inc groups B (Coetzee et al., 1982), C (Sirgel et al., 1981), FI to FIV (Jacob et al., 1977), $\mathrm{F}_{0}$ lac (Bradley et al., 1981 c), HII (Bradley et al., 1982b), $\mathrm{I}_{1}, \mathrm{I}_{2}$ (Coetzee et al., 1982), J (Bradley et al., 1982a), N, P (Coetzee et al., 1979), T (Bradley et al., 1981 b), W (Coetzee et al., 1979) and X (Bradley et al., 1981a) were employed.

Bacteriophages. Lysis of bacterial strains by plasmid-specific phages MS2 (Davis et al., 1961), C-1 (Sirgel et al., 1981), $\mathrm{F}_{0}$ lac (Bradley et al., 1981 c), PR64FS (Coetzee et al., 1980), J (Bradley et al., 1982 a), $\mathrm{t}$ (Bradley et al., 1981 b) or X (Bradley et al., 1981a) were used to demonstrate constitutive pilus production by strains carrying appropriate 


\section{Table 1. Host range of phage $M$}

Drops of phage suspension (titre $5 \times 10^{9}$ p.f.u. $\mathrm{ml}^{-1}$ ) were spotted on lawns of organisms contained in top-layer agar. Phage propagation was determined as described in Methods.

\begin{tabular}{|c|c|c|c|c|}
\hline \multirow[b]{2}{*}{ Host } & \multirow{2}{*}{$\begin{array}{l}\text { Plasmid } \\
\text { Inc group }\end{array}$} & \multicolumn{2}{|c|}{$\begin{array}{c}\text { Plaque formation by } \\
\text { phage:* }\end{array}$} & \multirow[b]{2}{*}{ Plasmid reference } \\
\hline & & $\mathbf{M}$ & $\mathrm{X}$ & \\
\hline E. coli J53(RIP69) & M & + & + & Witchitz \& Gerbaud (1972) \\
\hline K. pneumoniae G162(RIP69) & $\mathbf{M}$ & + & + & Witchitz \& Gerbaud (1972) \\
\hline K. oxytoca G147(RIP69) & M & + & + & Witchitz \& Gerbaud (1972) \\
\hline S. typhimurium M827-2(RIP69) & $\mathrm{M}$ & + & + & Witchitz \& Gerbaud (1972) \\
\hline Sr. marcescens Sr4l(RIP69) & $\mathbf{M}$ & + & + & Witchitz \& Gerbaud (1972) \\
\hline P. morganii 2815(RIP69) & $\mathbf{M}$ & + & + & Witchitz \& Gerbaud (1972) \\
\hline P. mirabilis PM5006(RIP69) & $\mathrm{M}$ & $-(-)$ & $-(+)$ & Witchitz \& Gerbaud (1972) \\
\hline E. coli J53(R446b) & M & $+\dagger$ & $-(+)$ & Bradley et al. (1980) \\
\hline K. pneumoniae G162(R446b) & M & + & + & Bradley et al. (1980) \\
\hline E. coli $\mathrm{J} 53(\mathrm{R} 831 \mathrm{~b})$ & $\mathbf{M}$ & + & + & Bradley et al. (1980) \\
\hline P. mirabilis PM5006(R831b) & $\mathbf{M}$ & $-(-)$ & $-(+)$ & Bradley et al. (1980) \\
\hline Sr. marcescens $\mathrm{Sr} 41(\mathrm{R} 831 \mathrm{~b})$ & $\mathbf{M}$ & + & + & Bradley et al. (1980) \\
\hline E. coli J53(R471) & $\mathbf{M}$ & $-(-)$ & $-(+)$ & $\begin{array}{l}\text { Richards \& Datta (1979); } \\
\text { Hedges (1980) }\end{array}$ \\
\hline K. oxytoca G147(R471) & $\mathbf{M}$ & + & + & $\begin{array}{l}\text { Richards \& Datta (1979); } \\
\text { Hedges (1980) }\end{array}$ \\
\hline$K$. pneumoniae G162(N3) & $\mathbf{N}$ & - & + & Hedges $(1972)$ \\
\hline K. pneumoniae G162(RP4) & $\mathrm{P}$ & - & + & Coetzee et al. (1979) \\
\hline K. pneumoniae G162(RSa) & W & - & + & Coetzee et al. (1979) \\
\hline
\end{tabular}

* + , Plaque formation to titre; - , no visible action. Signs in parentheses indicate results of bacteriophage propagation experiments.

$\dagger$ Approximately 30 -fold lower efficiency of plating.

plasmids. Phages C-1 and X were also used as controls in RNAase-chloroform and RNAase-diethyl ether sensitivity tests. The former phage is sensitive to RNAase but resistant to the organic solvents (Sirgel et al., 1981), while the latter is resistant to RNAase and diethyl ether but sensitive to chloroform (Bradley et al., 1981 a).

Media, antibiotics, transfer of plasmids by conjugation, general phage techniques, production of phage lysates and organic solvent sensitivity of phage. These were done as described and referred to by Coetzee et al. (1979) and Ackermann et al. (1978). The indicator organism for phage M (see below) was G162(RIP69); J62-1(P-lacR ldrd19) (Sirgel et al., 1981) and J53(R6K) (Bradley et al., 1981a) were the indicator strains for phages C-1 and X, respectively. The incubation temperature was $37^{\circ} \mathrm{C}$.

Phage isolation. Sewage specimens were obtained from various sewage works in the Pretoria area. Attempts were made to isolate a RIP69 plasmid-specific phage from sewage according to the method of Bradley et al. $(1981 a)$. The pairs of organisms used for enrichment of sewage with subsequent reciprocal testing for phage activity of the supernatants were J53-2(RIP69), M827-2(RIP69) and G162(RIP69), G147(RIP69). All enriched samples were then treated as before.

Ribonuclease sensitivity. This was done according to Bradley et al. (1981a) using the same phages and corresponding indicator strains mentioned above.

Bacteriophage propagation. Propagation of phages $\mathrm{M}$ (see below) and $\mathrm{X}$ was done as described by Coetzee et al. (1982). Briefly, an exponentially growing culture of the donor plasmid-bearing organism under test $(0 \cdot 1 \mathrm{ml})$ was mixed with an equal volume of stationary phase recipient (strains J53 or PM5006) on a Millipore membrane resting on nutrient agar. After overnight incubation, the growth was gently washed off by suspending the membrane in $5 \mathrm{ml}$ warm broth. To $1 \mathrm{ml}$ of this broth suspension, possibly containing transconjugants temporarily derepressed for pilus synthesis, were added $0.1 \mathrm{ml}$ phage suspension $\left(1 \times 10^{10}\right.$ p.f.u. $\left.\mathrm{ml}^{-1}\right)$ and $4 \mathrm{ml}$ soft top-layer and the mixture was poured over the surface of a nutrient agar plate and allowed to set. After overnight incubation, the phage was harvested and the titre on strain G162(RIP69) was determined. For the J53 system the recipient was J53 and donors were J53(R471) or J53(R446b). Donors and recipients for experiments with PM5006 were PM5006(RIP69) or PM5006(R831 b) and PM5006, respectively. Negative donor controls were J53 and PM5006, while the positive donor control was J53(RIP69) for both systems.

Concentration of phage. Phage $\mathrm{M}$ lysates were concentrated using polyethylene glycol (mol. wt 6000$)$ and $\mathrm{NaCl}$ at final concentration of $11 \%(\mathrm{w} / \mathrm{v})$ and $0.5 \mathrm{M}$, respectively (Yamamoto et al., 1970). Pellets were suspended in small volumes of distilled water. 
Electron microscopy. We found that when a culture of $E$. coli strain JE2571(R446) infected with phage M was shaken in broth, the culture fluids contained many free $\mathbf{M}$ pili with phage $\mathbf{M}$ virions attached. Accordingly, to demonstrate adsorption, $40 \mathrm{ml}$ Brain Heart Infusion Broth was inoculated with an overnight broth culture of JE2571(R446b) to a concentration of $5 \times 10^{7}$ organisms $\mathrm{ml}^{-1}$ and grown with shaking to a concentration of $1 \times 10^{8}$ organisms ml ${ }^{-1}$. Phage $\mathrm{M}(5 \mathrm{ml})$ at a titre of $1 \times 10^{9}$ p.f.u. $\mathrm{ml}^{-1}$ was then added and growth continued to a cell concentration of $2 \times 10^{9}$ organisms $\mathrm{ml}^{-1}$. No visible lysis occurred. After removing bacteria by centrifugation, a carbon-coated electron microscope specimen support grid was touched on the surface. The grid was washed by floating on successive baths of $0.1 \mathrm{M}$-ammonium acetate solution. Negative staining was done with a mixture of equal volumes of $2 \%(\mathrm{w} / \mathrm{v})$ sodium phosphotungstate and $0 \cdot 1 \mathrm{M}$-ammonium acetate solutions. To investigate the effect of chloroform on the structure of the phage $M$ virions, $5 \mathrm{ml}$ phage suspension was shaken with $5 \mathrm{ml}$ chloroform in a conical flask at room temperature for $2 \mathrm{~h}$ at 300 oscillations $\mathrm{min}^{-1}$. After standing for $30 \mathrm{~min}$ to allow the layers to separate, specimens were prepared for electron microscopy as described above. Magnification calibration was done with catalase.

\section{RESULTS}

\section{Isolation of a RIP69-dependent bacteriophage}

From the fifth sample of sewage [enriched with G162(RIP69)] a phage was isolated on G147(RIP69) which formed plaques on the former strain but not on isogenic strains lackıng the plasmid. The phage was named M and was routinely propagated on G162(RIP69).

\section{Properties of phage $M$}

Plaque morphology. The phage formed turbid plaques on all hosts where plaque formation was evident. Plaques varied from about $2 \mathrm{~mm}$ in diameter to less than $1 \mathrm{~mm}$ and the large plaques were usually irregular in outline.

Phage morphology and adsorption site. Phage $\mathrm{M}$ was morphologically similar to other RNAcontaining bacteriophages (Fig. $1 a, b$ ), having a semitransparent appearance in negatively stained preparations and a diameter of $27 \mathrm{~nm}$. The phage adsorbed more or less evenly along the whole of the $\mathrm{M}$ pilus shaft (Fig. $1 a, b$ ). Some virions had obviously become detached from pili during specimen preparation. A lysate of strain JE2571(R446b) contained many free M pili, $88 \%$ of which had one or more adsorbed virions (100 pilus sample). When 100 phage virions were scored, $81 \%$ were attached to pili. Phage virions less than 2 diameters from a pilus were considered attached (see Bradley et al., 1981 b; Coetzee et al., 1982).

Sensitivity to organic solvents or RNAase. The plaque-forming titre of a phage $\mathbf{M}$ suspension was reduced by $80 \%$ as a result of chloroform treatment, whereas the titre of phage C- 1 was unaffected. The titre of phage $\mathrm{X}$ was reduced by more than $99 \%$ following similar exposure. Titres of phage $M$ and the latter two phages were not reduced by diethyl ether treatment. Plaque formation by phages $\mathrm{M}$ and $\mathrm{C}-1$ was totally inhibited by RNAase, whereas that of phage $\mathrm{X}$ was unaffected.

Chloroform treatment of the phage $M$ lysate described above (see Methods) detached all virions from the $\mathbf{M}$ pili. Phage inactivation appeared to be due to rupture of the capsid, this being the structural change observed; not all virions were completely disintegrated. A typical example (Fig. 1 c) shows a virion with the break in the capsid arrowed. A count of 50 chloroformtreated virions revealed that 42 were ruptured, 8 remaining apparently intact. This agreed closely with the $80 \%$ reduction in titre that was obtained (see above). No ruptured particles were seen in control suspensions shaken in the absence of chloroform.

Host range. Unlike the filamentous phage X (Bradley et al., 1981a) which also plated on Klebsiella strain G162 carrying plasmids belonging to Inc groups N, P and W, phage M plated only on strains harbouring plasmids of the $\mathbf{M}$ group (Table 1 and not shown) and not on any other strains carrying plasmids belonging to other incompatibility groups tested. The $M$ plasmid-bearing strains were derived from a number of bacterial genera. Neither phage $\mathrm{X}$ nor $\mathbf{M}$ formed plaques on $P$. mirabilis PM5006 harbouring various IncM plasmids (Table 1 and not shown). The latter strains also failed to propagate phage $\mathbf{M}$ (Table 1 and not shown) although 


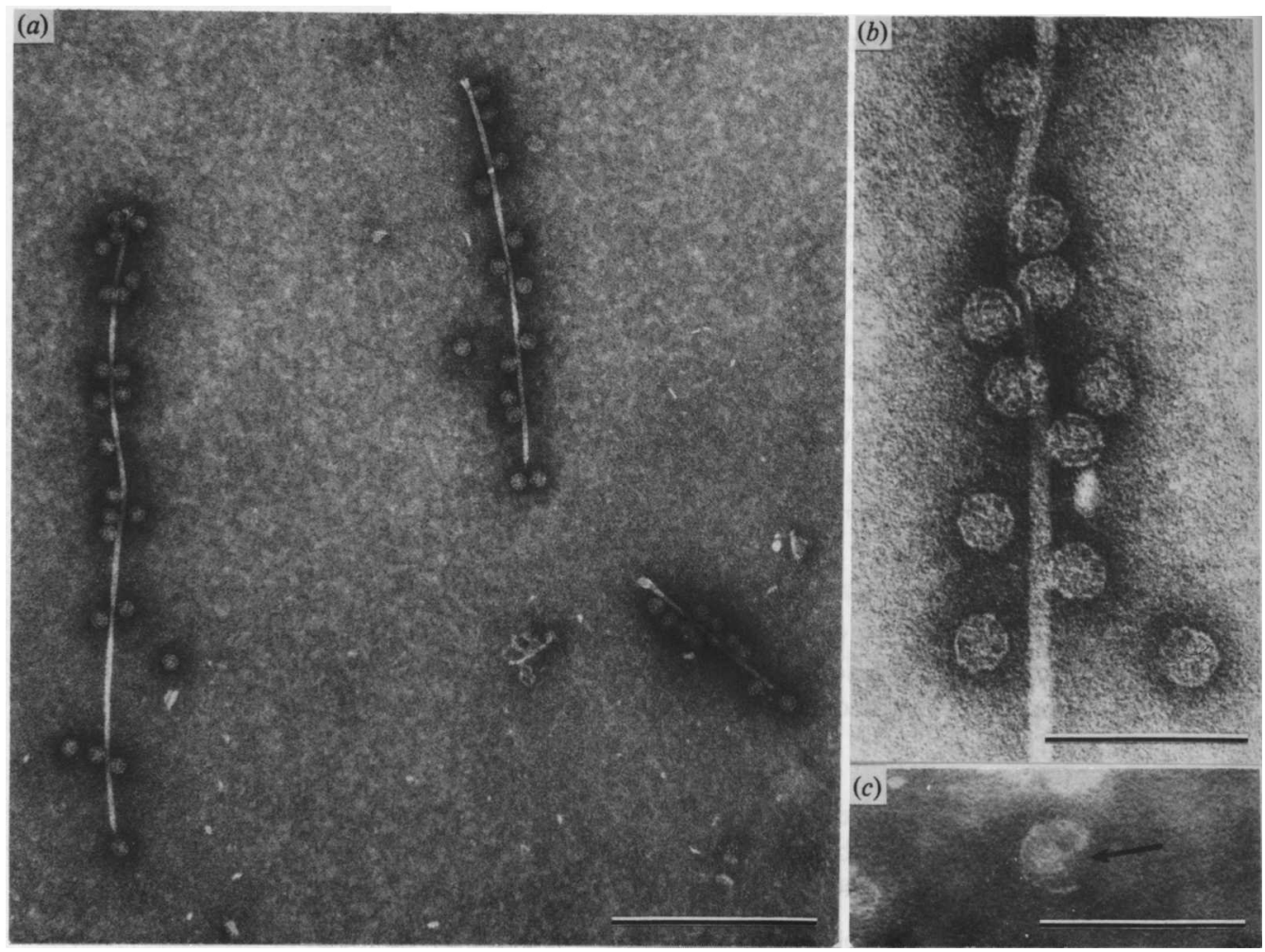

Fig. 1. (a) RNA phage $\mathbf{M}$ virions adsorbed along the shafts of $\mathbf{M}$ pili, from a lysate of $E$. coli strain JE2571(R446b) grown in nutrient broth. (b) High magnification electron micrograph of phage $\mathbf{M}$ virions showing similarity to other RNA phages. The virions near the bottom are presumed to have become detached from the pilus during specimen preparation. (c) Phage $\mathbf{M}$ virion with a break (arrow) in its capsid after chloroform treatment (see Methods). The bar markers represent $100 \mathrm{~nm}$.

phage $X$ registered a titre increase (Table 1 and not shown). The phages did not plate on $E$. coli strain J53 carrying the IncM plasmid R471 although this strain propagated phage X. Plasmid $\mathrm{R} 446 \mathrm{~b}$ conferred only partial phage sensitivity on this strain of $E$. coli (Table 1 and see Bradley $e t$ al., 1981 a). Plaque formation was evident on Klebsiella strains carrying either of these plasmids (Table 1).

\section{DISCUSSION}

Although $M$ plasmids have been identified in a wide range of bacterial species including members of the Escherichieae and Proteeae (Hedges et al., 1973; Chabbert \& Roussel, 1977), they seem to be most closely associated with the Klebsielleae and form a high proportion of the $\mathrm{R}$ plasmids of this tribe (Witchitz \& Gerbaud, 1972; Severn, 1977; Davey \& Pittard, 1977; Romero et al., 1978; Richards \& Datta, 1979; Datta et al., 1979; O'Brien et al., 1980; Hedges, 1980). In all the above cases, $M$ plasmids conferring significant resistance to antibiotics in hospital outbreaks were detected in members of the Klebsielleae but transfer to bacteria of other tribes was noted in most instances. Since a phage dependent for adsorption upon the pili determined by $\mathbf{M}$ plasmids must be expected to be adapted for growth in those cells in which such plasmids occur, we chose a $K$. pneumoniae strain carrying M plasmid RIP69 as host for selection of the new phage. This precaution proved unnecessary since phage $\mathbf{M}$ could grow on $\mathrm{M}^{+}$strains of at least three other tribes of Enterobacteriaceae (Table 1). Thus, phage $\mathrm{M}$ is adapted to exploit the host range of M plasmids like phage PRR1 which lyses many hosts of the wide 
host-range IncP-1 plasmids (Olsen \& Thomas, 1973). The capacity of Pseudomonas strains to serve as hosts for the phage could not be tested as IncM plasmids do not transfer to these strains (J. N. Coetzee, unpublished; Jacoby, 1975).

Plasmids RIP69 and R831b clearly encoded constitutive production of phage receptors in all strains tested apart from P. mirabilis PM5006 (Table 1 and not shown; Bradley et al., 1980; $1981 a$ ). The phenomenon of plasmid-specific phages not forming plaques or not propagating on species of all bacterial genera harbouring a plasmid which confers sensitivity, has been encountered repeatedly (Olsen \& Thomas, 1973; Bradley, 1977; Bradley et al., 1981 a; Coetzee et al., 1979; Sirgel et al., 1981; Hua et al., 1981). The behaviour of plasmids RIP69 and R831b in $P$. mirabilis PM5006 and plasmids R471 and R446b in E. coli strain J53 may be further examples (Table 1).

With the discovery of phage M, IncM plasmid-coded pili join those of Inc groups C (Sirgel et al., 1981), FI to FIV (Jacob et al., 1977; Datta, 1979; Dennison \& Hedges, 1972), $\mathrm{F}_{0}$ lac (Bradley et al., 1981 c), I, (Coetzee et al., 1982), P-1 (Olsen \& Thomas, 1973) and T (Bradley et al., 1981 b) in possessing adsorption sites for specific RNA-containing phages.

$\mathrm{M}$ pili are the only rigid pili (Bradley, 1980b) described to date which possess RNA phage adsorption sites, except for P-1 pili, which are thinner than M pili (Bradley, 1980b) and which adsorb the RNA-containing phage PRR1 (Olsen \& Thomas, 1973). Structural differences between phage $M$ and the RNA phages adsorbing to the flexible pili mentioned above would thus possibly not be unexpected. The only such difference encountered was the sensitivity of the phage to chloroform (Fig. 1c).

The expert technical assistance of Mrs Laureen du Toit, Monica Tweehuysen and Mrs Sarie Theron is gratefully acknowledged. D. E. B. acknowledges the support of the Medical Research Council of Canada (Grant no. MA5608). Dr W. O. K. Grabow of the National Institute of Water Research is thanked for providing many of the sewage samples examined.

\section{REFERENCES}

Ackermann, H.-W., Audurier, A., Berthiaume, L., Jones, L. A., Mayo, J. A. \& VidAVer, A. K. (1978). Guidelines for bacteriophage characterization. $A d$ vances in Virus Research 23, 1-24.

BRADley, D. E. (1977). Characterization of pili determined by drug resistance plasmids $\mathrm{R} 711 \mathrm{~b}$ and R778b. Journal of General Microbiology 102, 349363.

BRADLEY, D. E. $(1980 a)$. Determination of pili by conjugative bacterial drug resistance plasmids of incompatibility groups $\mathrm{B}, \mathrm{C}, \mathrm{H}, \mathrm{J}, \mathrm{K}, \mathrm{M}, \mathrm{V}$ and $\mathrm{X}$. Journal of Bacteriology 141, 828-837.

Bradley, D. E. (1980 b). Morphological and serological relationships of conjugative pili. Plasmid 4, 155169.

Bradley, D. E., Taylor, D. E. \& Cohen, D. R. (1980). Specification of surface mating systems among conjugative drug resistance plasmids in Escherichia coli K-12. Journal of Bacteriology 143 , 1466-1470.

Bradley, D. E., Coetzee, J. N., Bothma, T. \& Hedges, R. W. $(1981 a)$. Phage X: a plasmiddependent, broad host range, filamentous bacterial virus. Journal of General Microbiology 126, 389-396.

Bradley, D. E., Coetzee, J. N., Bothma, T. \& Hedges, R. W. (1981 b). Phage t : a group T plasmiddependent bacteriophage. Journal of General Microbiology 126, 397-403.

Bradley, D. E., Coetzee, J. N., Bothma, T. \& Hedges, R. W. $\left(1981 c\right.$ ). Phage $\mathrm{F}_{0}$ lac: an $\mathrm{F}_{0}$ lac plasmid-dependent bacteriophage. Journal of General Microbiology 126, 405-411.
Bradley, D. E., Sirgel, F. A., Coetzee, J. N., Hedges, R. W. \& Coetzee, W. F. (1982a) Phages C2 and $\mathbf{J}$ : IncC and Inc J plasmid-dependent phages, respectively. Journal of General Microbiology 128, 2485-2498.

Bradley, D. E., Hughes, V. M., Richards, H. \& DATTA, N. (1982b). R plasmids of a new incompatibility group determine constitutive production of $\mathrm{H}$ pili. Plasmid 7, 230-238.

Chabbert, Y. A. \& Roussel, A. (1977). Taxonomy and epidemiology of $\mathbf{R}$ plasmids as molecular species. Journal of Antimicrobial Chemotherapy 3 (suppl. C), 24-33.

Chabbert, Y. A., Slavizzi, M. R., Witchitz, J. H., Gerbaud, G. R. \& Bounanchaud, D. H. (1972). Incompatibility groups and the classification of $\mathrm{fi}^{-}$ resistance factors. Journal of Bacteriology 112, 666675.

Coetzee, J. N. (1972). Genetics of the Proteus group. Annual Review of Microbiology 26, 23-54.

Coetzee, J. N. \& SMit, J. A. (1970). Properties of Proteus mirabilis phage 13vir. Journal of General Virology 9, 247-249.

Coetzee, J. N., Lecatsas, G., Coetzee, W. F. \& Hedges, R. W. (1979). Propertiès of R plasmid R772 and the corresponding pilus-specific phage PR772. Journal of General Microbiology 110, 263-273.

Coetzee, J. N., Sirgel, F. A. \& Lecatsas, G. (1980). Properties of a filamentous phage which adsorbs to pili coded by plasmids of the IncI complex. Journal of General Microbiology 117, 547-551.

Coetzee, J. N., Bradley, D. E. \& Hedges, R. W. 
(1982). Phages $\mathrm{I} \alpha$ and $\mathrm{I}_{2}-2$ : IncI plasmid-dependent bacteriophages. Journal of General Microbiology 128 , 2797-2804.

DatTA, N. (1975). Epidemiology and classification of plasmids. In Microbiology-1974, pp. 5-15. Edited by D. Schlessinger. Washington, D.C.: American Society for Microbiology.

DATTA, N. (1977). Classification of plasmids as an aid to understanding their epidemiology and evolution. Journal of Antimicrobial Chemotherapy 3 (suppl. C), 19-23.

DatTA, N. (1979). Plasmid Classification: incompatibility grouping. In Plasmids of Medical, Environmental and Commercial Importance, pp. 3-12. Edited by K. M. Timmis and A. Puhler. Amsterdam: Elsevier/North Holland Biomedical Press.

Datta, N., Hughes, V. M., Nugent, M. E. \& Richards, H. R. (1979). Plasmids and transposons and their stability and mutability in bacteria isolated during an outbreak of hospital infection. Plasmid 2, 182-196.

Datta, N., Dacey S., Hughes, V., Knight, S., Richards, H., Williams, G., Casewell, N. \& Shannon, K. P. (1980). Distribution of genes for trimethoprim and gentamicin resistance in bacteria and their plasmids in general hospital. Journal of General Microbiology 118, 495-508.

Davey, R. B. \& Pittard, J. (1977). Plasmids mediating resistance to gentamicin in enterobacteriaceae from four hospitals in Melbourne. Australian Journal of Experimental Biological and Medical Science 55, 299-307.

Davis, J. E., Strauss, H. J. \& Sinsheimer, R. L. (1961). Bacteriophage MS2: another RNA phage. Science 134, 1427

Dennison, S. \& Hedges, R. W. (1972). Host specificities of RNA phages. Journal of Hygiene 70, 55-61.

Hedges, R. W. (1972). Phenotypic characterization of $f^{-} \mathrm{R}$ factors determining the restriction and modification of hsp II specificity. Molecular and General Genetics 115, 225-233.

Hedges, R. W. (1980). R factors of Serratia. In The Genus Serratia pp. 139-153. Edited by A. von Graevenitz \& S. J. Rubin. Boca Raton, Florida: CRC Press.

Hedges, R. W., Datta, N., Coetzee, J. N. \& DenNison, S. (1973). R factors from Proteus morganii. Journal of General Microbiology 77, 249-259.

Hedges, R. W., Rodriguez-Lemoine, V. \& DatTa, N. (1975). R factors from Serratia marcescens. Journal of General Microbiology 86, 88-92.

Hua, T.-C., Scholl, D. R. \& Jollick, J. D. (1981). Functional modification of the plasmid RP1-specified pilus by Caulobacter vibrioides. Journal of General Microbiology 124, 119-128.
Jacob, A. E., Shapiro, J. A., Yamamoto, L., Smith, D. I., Cohen, S. N. \& Berg, D. (1977). Plasmids studied in Escherichia coli and other enteric bacteria. In DNA Insertion Elements, Plasmids and Episomes, pp. 607-638. Edited by A. I. Bukhari, J. A. Shapiro \& S. L. Adhya. New York: Cold Spring Harbor Laboratory.

JACOBY, G. A. (1975). Properties of R plasmids in Pseudomonas aeruginosa. In Microbiology-1974, pp. 36-42. Edited by D. Schlessinger. Washington, D.C.: American Society for Microbiology.

Matsumoto, H., Tazaki, T. \& Hosogaya, S. (1973). A generalized transducing phage of Serratia marcescens. Japanese Journal of Microbiology 17, 473-479.

Morgan, H. DE R. (1906). Upon the bacteriology of the summer diarrhoea of infants. British Medical Journal 1, 908-912.

Novick, R. P., Clowes, R. C., Cohen, S. N., Curtiss III, R., DatTa, N. \& FalKow, S. (1976). Uniform nomenclature for bacterial plasmids: a proposal. Bacteriological Reviews 40, 168-189.

O'Brien, T. F., Ross, D. G., Guzman, M. A., Medeiros, A. A., Hedges, R. W. \& Botstein, D. (1980). Dissemination of an antibiotic resistance plasmid in hospital bacterial flora. Antimicrobial Agents \& Chemotherapy 17, 537-543.

OLSEN, R. H. \& ThOMAS, D. D. (1973). Characteristics and purification of PRR1, an RNA phage specific for the broad host range Pseudomonas R1882 drug resistance plasmid. Journal of Virology 12, 1560 1567.

Richards, H. R. \& DATTA, N. (1979). Reclassification of incompatibility group L (IncL) plasmids. Plasmid 2, 293-295.

Romero, E., Perduca, M. \& Pagani, L. (1978). R factors from Enterobacter group. Bolletino dell'Istituto sieroterapico milanese 57, 20-22.

SEVERN, M. (1977). Gentamicin resistant Serratia. Lancet 1, 750.

Sirgel, F. A., Coetzee, J. N., Hedges, R. W. \& Lecatsas, G. (1981). Phage C-1: an IncC group plasmid-specific phage. Journal of General Microbiology 122, 155-160.

Spratt, B. G., Rowbury, R. H. \& Meynell, G. G. (1973). The plasmid of Salmonella typhimurium LT2. Molecular and General Genetics 121, 347-353.

Witchitz, J. L. \& Gerbaud, G. R. (1972). Classification de plasmides conférant la résistance a la gentamicine. Annales de l'Institut Pasteur 123, 333339.

Yamamoto, K. R., Alberts, B. M., Benzinger, R., LAWHORNe, L. \& TREIBER, G. (1970). Rapid bacteriophage sedimentation in the presence of polyethylene glycol and its application to large-scale virus purification. Virology 40, 734-744. 